\title{
Synthesis, reactions and biological activity of 11-azaartemisinin and derivatives
}

\author{
Jo Alen, ${ }^{a}$ Bich Ngan Truong,, ${ }^{\text {a,b }}$ Van Hung Nguyen, ${ }^{b}$ and Wim Dehaen ${ }^{a^{*}}$ \\ ${ }^{a}$ Department of Chemistry, Katholieke Universiteit Leuven, Celestijnenlaan 200F - bus 2404, \\ B-3001 Heverlee, Belgium \\ ${ }^{b}$ Institute of Marine Biochemistry - Vietnam Academy of Science and Technology (VAST), \\ 18 Hoang Quoc Viet Road, Cau Giay, Hanoi, Vietnam \\ E-mail: Wim.Dehaen@chem.kuleuven.be
}

\begin{abstract}
In this review, we will give an overview of the synthesis and reactions of 11-azaartemisinins and their derivatives, from the first report in 1995 till now. The desoxo as well as the 9-desmethyl analogues are included. The biological activity of the azaartemisinins is also briefly discussed, with an emphasis on their potency as antimalarials. Computational studies on this type of compounds are beyond the scope of this review and will not be discussed, nor referenced.
\end{abstract}

Keywords: Azaartemisinin, antimalarial, natural product, artemisinin

\section{Table of Contents}

1. Introduction

2. 11-Azaartemisinins

2.1 Conversion of artemisinin to azaartemisinin

2.2 Michael additions to 11-azaartemisinins

$2.3 \mathrm{~N}$-amino and hydroxy- 11-azaartemisinins

2.4 N-Biotinylated azaartemisnin derivatives

2.5 11-Azaartemisinin desoxo derivatives

2.6 11-Aza-9-desmethylartemisinins

3. Conclusions

4. Acknowledgements

5. References 


\section{Introduction}

Malaria is still one of the most widespread parasitic diseases. Annually 1-2 million deaths are caused by malaria worldwide. Though 4 species of anopheles can infect man (Plasmodium falciparum, $P$. vivax, $P$. malariae and $P$. ovale), almost all the deaths are caused by $P$. falciparum, as a result of cerebral malaria.

Artemisinin 1 was identified in 1972 as the active ingredient of Artemisia annua, a Chinese herb that has been used since 341 B.C. for the treatment of severe fevers. ${ }^{1}$ Despite several positive studies of both Chinese and Western researchers, the potential of artemisin was underestimated for years. ${ }^{2}$ Currently, artemisinin derivatives are recommended by the World Health Organization (WHO) for the treatment of malaria, especially as part of a combination therapy, whereby artemisinin derivatives are administered together with other antimalarials. Because of the poor solubility of artemisinin in both water and oil, some simple more soluble derivatives were developed. The clinically used artemisinin derivatives are dihydroartemisinin 2 (DHA), artemether $\mathbf{3}$, artemotil $\mathbf{4}$ and artesunate $\mathbf{5}$ (Structure block 1).
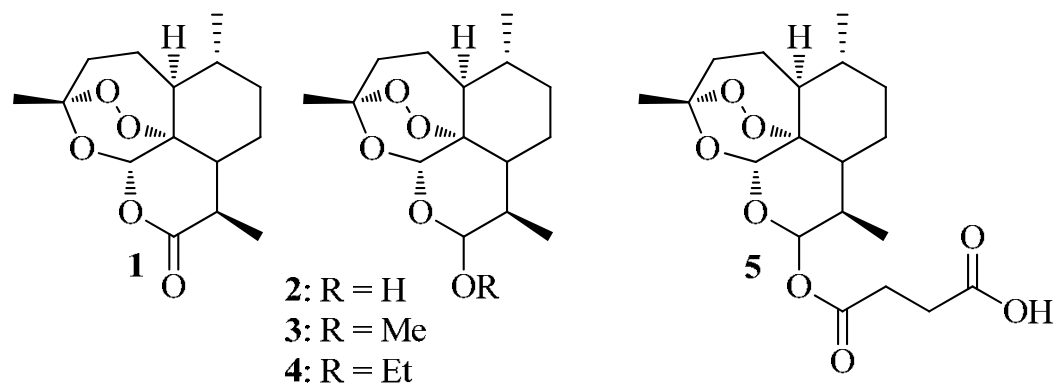

Structure block 1. Artemisinin and clinically used derivatives.

\section{11-Azaartemisinins}

Oral use of artemisinin $\mathbf{1}$ and its derivatives is mostly restricted due to the labile nature of the peroxide and facile hydrolysis of the lactone by acid in the stomach. Therefore a more stable core was pursued. One of the possible solutions was substituting the lactone by the more stable lactam function.

\subsection{Conversion of artemisinin to azaartemisinins}

Until 1995, all of the reaction sequences for the decoration of the artemisinin scaffold left the tetracyclic ring system intact. Most of the artemisinin derivatives were limited to preparing the corresponding esters, ethers, carbonates and urethanes of dihydroartemisinin. The group of Ziffer was the first to communicate a novel reaction sequence, that started with the opening of the lactone to produce an amide, whereby the tetracyclic ring system is reformed in the process of converting the amide into a lactam (Scheme 1$).^{3}$ 

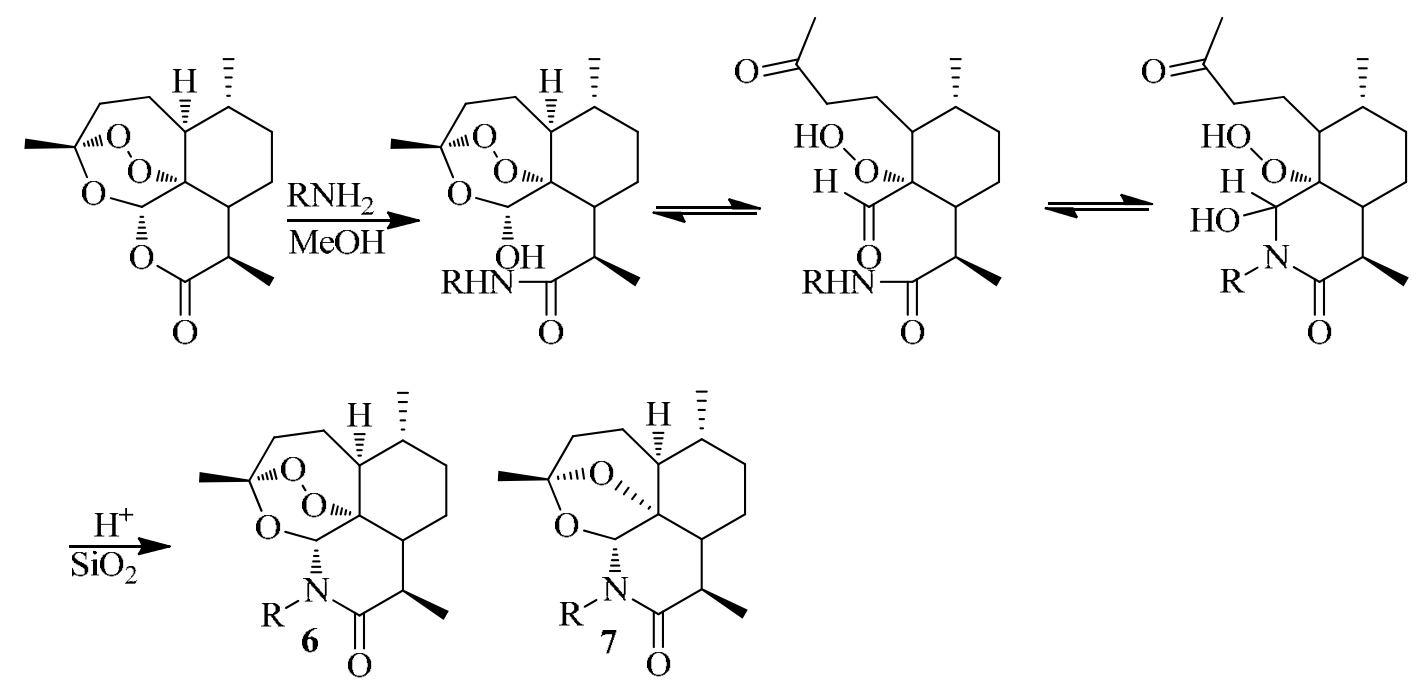

Scheme 1. Conversion of artemisinin to 11-azaartemisinin.

Reaction of artemisinin 1 with methanolic ammonia led to a complex mixture that was partially identified by ${ }^{1} \mathrm{H}$ NMR. This reaction mixture was subjected to reaction conditions developed by Avery et al. to synthesize artemisinin derivatives (silica gel, dilute sulfuric acid and BHT). ${ }^{4}$ This yielded two compounds $\mathbf{6 a}$ and $7 \mathbf{a}$ in $45 \%$ and $9 \%$ isolated yield respectively. The structure of the major compound $\mathbf{6 a}$ was characterized by mass spectrometry (CI-MS indicated that its molecular weight was 1 dalton less than artemisinin) and ${ }^{1} \mathrm{H}$ and ${ }^{13} \mathrm{C}$ NMR data. Employing ${ }^{15} \mathrm{NH}_{3}$ yielded additional information, such as coupling between $\mathrm{H}-12$ and ${ }^{15} \mathrm{~N}(J=$ $86.9 \mathrm{~Hz})$ and coupling of ${ }^{15} \mathrm{~N}$ with $\mathrm{C}-10(J=11.9 \mathrm{~Hz})$ and C-12 $(J=10.3 \mathrm{~Hz})$, as well as a two bond coupling to C-9 $(J=5.9 \mathrm{~Hz})$. The second compound was identified as $N$-containing deoxy compound 7a.

When Amberlyst was used instead of $\mathrm{H}_{2} \mathrm{SO}_{4} / \mathrm{SiO}_{2}$, the yield of the desired compound increased to $65 \%$ and formation of the deoxy analogue was not observed. ${ }^{5}$ An attempt to allylate the $\mathrm{N}$-atom of $\mathbf{6 a}$ with allyl bromide in the presence of silver oxide exclusively led to the undesired $O$-allyl derivative 8 (Scheme 2). Fortunately, the former approach is easily extended to prepare $\mathrm{N}$-substituted 11-azaartemisinins using alkyl-, aromatic, or heteroaromatic amines instead of ammonia. It appears to be necessary to remove any unreacted amine present in the reaction before acid treatment, to prevent unwanted formation of the deoxy compounds, either by removal in vacuo (volatile amines) or extraction of a DCM solution of the reaction mixture with an aqueous citrate buffer ( $\mathrm{pH}$ 4.5). Incorporating a lipophilic or hydrophilic substituent could provide a way to control the solubility. 

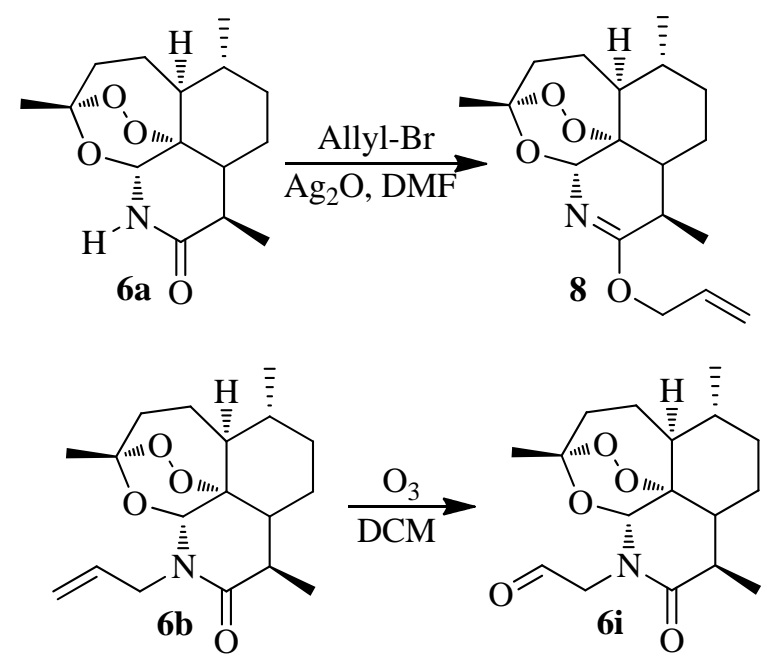

Scheme 2. $O$-Allylation of azaartemisinin and ozonolysis of $N$-allylated azaartemisinin.

The azaartemisinins $\mathbf{6}$ and $\mathbf{7}$ of Ziffer $^{5}$ were screened against a chloroquine-resistant strain (FCR3) of $P$. falciparum. As expected, the deoxy compounds 7 did not show any activity. The in vitro results showed that three of the compounds had antimalarial activities one order of magnitude larger than that of artemisinin (Table 1). Biological tests showed that compound $\mathbf{6 i}$ (Scheme 2, Table 1) was 26 times more active in vitro and 4 times more active than artemisinin (= approximately as active as $\beta$-arteether) in vivo (against $P$. berghei in mice). This compound $\mathbf{6 i}$ was obtained by reductive ozonolysis of the $N$-allyl analog $\mathbf{6 b}$ (Scheme 2).

An attempt of the McPhail group to reproduce the results of Ziffer et al., ${ }^{5}$ surprisingly led to the formation of some by-products (Scheme 3). ${ }^{6}$ Reaction of artemisinin with anhydrous ammonia, yielded the expected products $\mathbf{6 a}$ and 7, along with the isolation of $25 \%$ of $\mathbf{9}$. Monocyclic 9 is postulated to arise from reaction of artemisinin with ammonia, followed by an internal Baeyer-Villiger oxidation to give the formate ester 10, that intramolecularly rearranges to 9. Substituting ammonia by allylamine gave analogous compounds. In the case of methylamine however, an additional product $\mathbf{1 1}$ was isolated in 32\% yield. Remarkable is the inversion of the stereochemistry at C-7, relative to artemisinin, as was confirmed by singlecrystal X-ray analysis. Formation of this product can be explained by a mechanism that involves acid hydrolysis of 10a, followed by an aldol-type condensation. Subsequent Michael addition of the amide group to the $\alpha, \beta$-unsaturated ketone in the intermediate leads to the observed product 11. 
Table 1. In vitro antimalarial activity of azaartemisinins 6 and desoxo azaartemisinins 7

\begin{tabular}{|c|c|c|c|c|c|}
\hline & c & $\begin{array}{c}\text { In vitro } \\
\text { antimalarial } \\
\text { activity against } \\
\text { the FCR3 clone } \\
\text { of } P \text {. falciparum }\end{array}$ & & & $\begin{array}{c}\text { In vitro } \\
\text { antimalarial } \\
\text { activity against } \\
\text { the FCR3 clone } \\
\text { of } P \text {. falciparum }\end{array}$ \\
\hline Compd & $\mathrm{R}$ & $\begin{array}{c}\mathrm{IC}_{50}(1) / \mathrm{IC}_{50} \\
\text { (Compd) }\end{array}$ & Compd & $\mathrm{R}$ & $\begin{array}{c}\mathrm{IC}_{50}(1) / \mathrm{IC}_{50} \\
\text { (Compd) }\end{array}$ \\
\hline $6 a$ & $\mathrm{H}$ & 1.0 & $7 a$ & $\mathrm{H}$ & 0.01 \\
\hline $6 b$ & $\mathrm{CH}_{2} \mathrm{CH}=\mathrm{CH}_{2}$ & 0.8 & $7 \mathbf{b}$ & $\mathrm{CH}_{2} \mathrm{CH}=\mathrm{CH}_{2}$ & 1 \\
\hline 6c & $\mathrm{CH}_{2} \mathrm{CH}\left(\mathrm{CH}_{3}\right)_{2}$ & 9.0 & 7c & $\mathrm{CH}_{2} \mathrm{CH}\left(\mathrm{CH}_{3}\right)_{2}$ & 0.001 \\
\hline 6d & $\mathrm{CH}_{3}$ & 2.6 & $7 d$ & $\mathrm{CH}_{3}$ & I \\
\hline $6 e$ & $\mathrm{CH}_{2} \mathrm{Ph}$ & / & $7 e$ & $\mathrm{CH}_{2} \mathrm{Ph}$ & l \\
\hline $6 f$ & 2-pyridylmethyl & 22.0 & $7 f$ & 2-pyridylmethyl & 0.008 \\
\hline $6 g$ & 2-furylmethyl & 1.0 & $7 g$ & 2-furylmethyl & l \\
\hline $6 \mathrm{~h}$ & 2-thienylmethyl & 1.1 & & & \\
\hline $6 \mathbf{i}$ & $\mathrm{CH}_{2} \mathrm{CHO}$ & 26.0 & & & \\
\hline
\end{tabular}

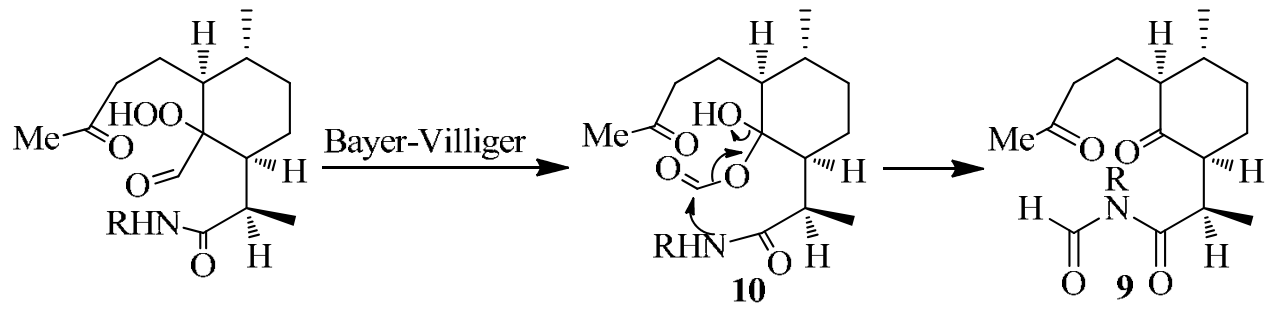

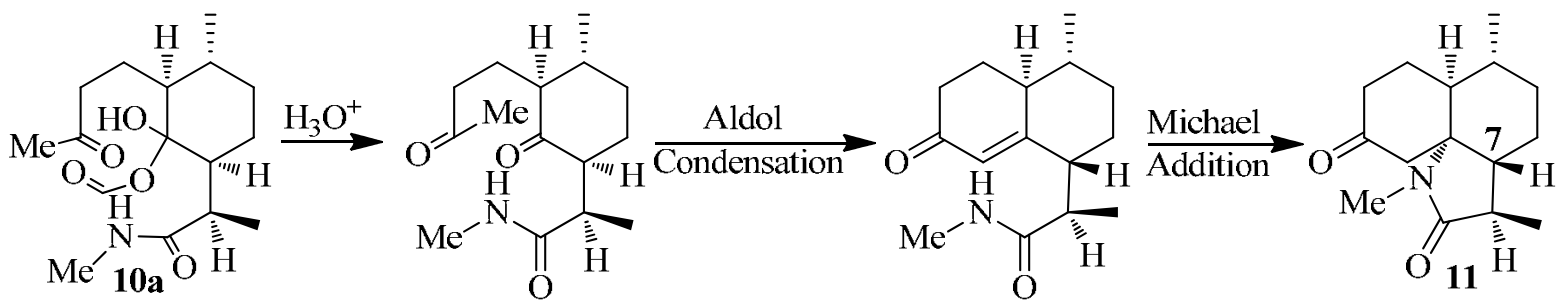

Scheme 3. Postulated reaction mechanisms for the by-products 9 and 11.

When the work of Ziffer ${ }^{3}$ was repeated by the group of Haynes, ${ }^{7}$ they found that in their hands identical reaction conditions (reaction of $\mathbf{1}$ in $\mathrm{MeOH}$ with ammonia, benzylamine or other primary amines; followed by removal and treatment of the crude residue in DCM with silica gel $/ \mathrm{H}_{2} \mathrm{SO}_{4}$ or $p$-TsOH) gave the deoxy compound 7 exclusively. Lowering the reaction temperature in DCM to $0-5{ }^{\circ} \mathrm{C}$, followed by acid treatment, yielded 11-azaartemisinins 6 in 
moderate yield, together with the desoxo compound 7 in about $40 \%$ yield. At higher temperatures, desoxo compound 7 was the major product.

Upon treatment of artemisinin (2eq) with a tertiary amine ( $N$-methylmorpholine, 5eq), no reaction was observed. However, addition of benzylamine (1eq) to this reaction mixture gave the $N$-oxide 12 in 72\% isolated yield, along with the desoxo compound 7j (R = Bn) (Scheme 4). Optimal reaction conditions consisted of a two phase system (water/DCM) followed by extraction of the $N$-oxide into the water layer (60\% yield of $N$-oxide after purification). The organic phase contained azadesoxoartemisinin $\mathbf{7} \mathbf{j}$ as the major product, as well as up to $10 \%$ of recovered artemisinin and small quantities of desoxoartemisinin. Other tertiary amines underwent analogous reactions.

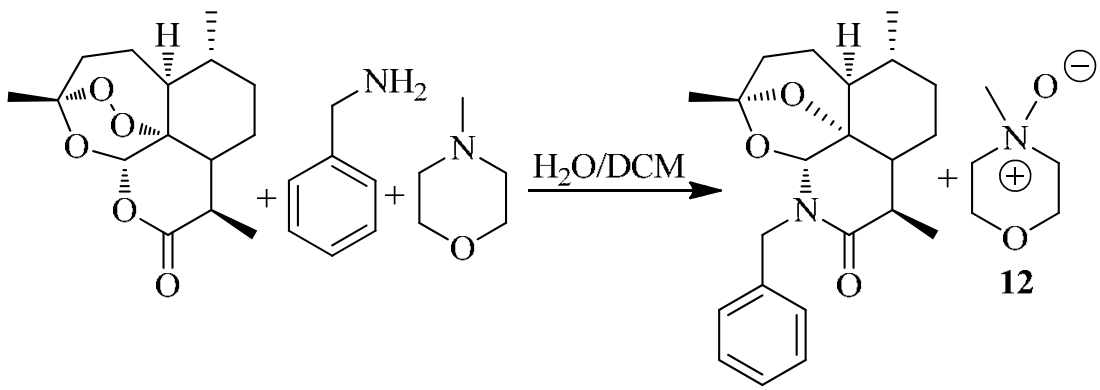

Scheme 4. Formation of deoxy artemisinin.

Haynes and co-workers later on optimized the reaction conditions for the synthesis of the unsubstituted lactam 6a. ${ }^{8}$ Artemisinin was treated with $33 \%$ aqueous ammonium hydroxide in a 10:3 THF:methanol mixture at -15 to $-10{ }^{\circ} \mathrm{C}$, followed by solvent removal under reduced pressure and treating the crude residue with $p \mathrm{TsOH}$ in DCM at ambient temperature. The desired product 6 a could be easily obtained in $70 \%$ yield by crystallization on multi-gram scale.

\subsection{Michael additions to 11-azaartemisinins}

To elaborate on their previous lead, ${ }^{5}$ the group of Ziffer pursued an efficient and direct route to analogs of $\mathbf{6 i}$. $^{9}$ Considering that treatment with alkylation agents was not an option (as this approach leads to the $O$-alkyl derivatives), the Michael addition to 6a was investigated as an alternative. Reaction of $\mathbf{6 a}$ with catalytic amounts of sodium hydroxide, and ethyl acrylate in THF at room temperature, yielded the desired $N$-alkyl derivative 13 in $86 \%$ yield (Scheme 5, left arrow). This procedure was easily extended towards other electron withdrawing groups (EWGs) on the double bond (e.g. nitriles, ketones, sulfonates, sulfones, and sulfoxides, succinic diesters) to prepare the desired adducts in 70-90\% yields. However, a second substituent on the double bond (either in $\alpha$ - or $\beta$-position) completely prevented the addition of the amide moiety.

In a follow-up paper, Ziffer and co-workers investigated the addition of the lactam 6a to terminal acetylenes conjugated to EWGs (Scheme 5, right arrow). ${ }^{10}$ While reaction with methyl propiolate and DMAP in acetonitrile yielded the product $\mathbf{1 4}$ in high yield after short reaction 
time, the additions of $\mathbf{6 a}$ to 3-butyn-2-one and $N, N$-dimethyl propiolamide were much more sluggish and incomplete. NMR analysis of the adduct suggests $E$-stereochemistry of the double bond, based on the magnitude of the coupling constant $J_{13-14}(14-16 \mathrm{~Hz})$.

However, when the EWG was a nitrile, both isomers were formed, with the major product (40\% isolated yield) possessing the Z-geometry $\left(J_{13-14}=11 \mathrm{~Hz}\right){ }^{11}$ The minor E-adduct $\left(J_{13-14}=\right.$ $15 \mathrm{~Hz}$ ) was only formed in 4\% yield. Changing the solvent from acetonitrile to DMF did not have any effect on the stereochemistry of the reaction.

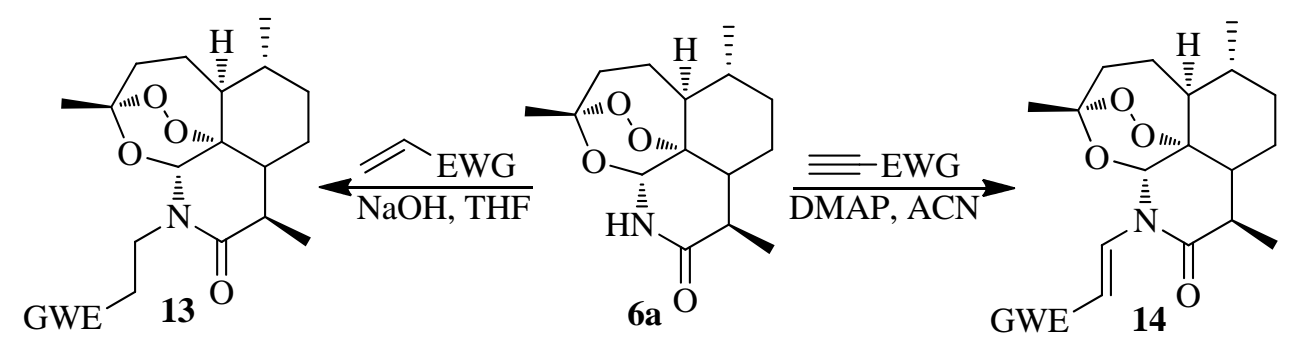

Scheme 5. Michael additions on azaartemisinin.

The noteworthy activity of $\mathbf{6 i}$, with an aldehyde function on the $\beta$-carbon of the nitrogen atom, prompted Ziffer et al. to further investigate whether other electronegative substituents at the $\gamma$-carbon of the substituent on the lactam nitrogen atom, could further increase the antimalarial activity. ${ }^{11}$ Therefore, the adduct of 11-azaartemisinin with methyl acrylate 13g was reduced with DIBAL to yield a mixture of alcohol 13h and aldehyd 13i (Scheme 6). The aldehyd was further reacted with methyl lithium or phenyl lithium respectively, after which the resulting

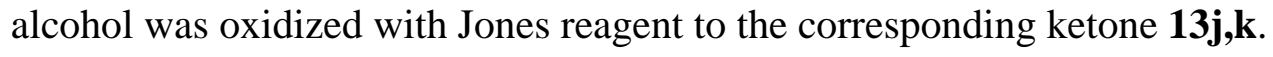

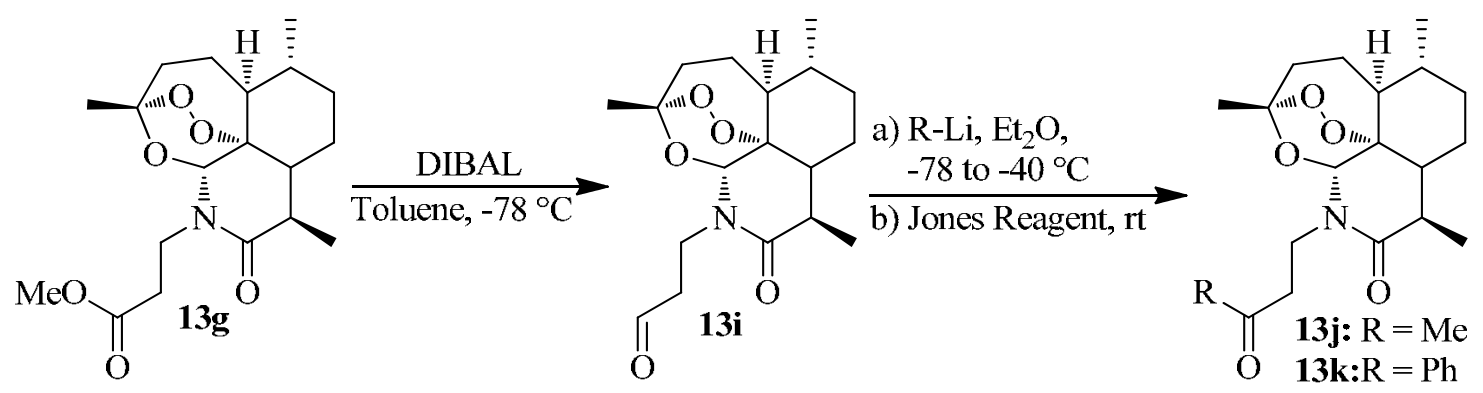

Scheme 6. Conversion of Michael adduct with ester function to ketone.

Of the fifteen azaartemisinins in Table 2, ten were more active than artemisinin against the D-6 clone and six were more active against the $\mathrm{W}-2$ clone. The activity increased significantly on converting the aldehyd $\mathbf{1 3 \mathbf { i }}$ into ketones 13j or 13k. Introducing a double bond did not cause a significant change in the antimalarial activity. Neither was a large effect observed by replacing the aldehyde group with $\mathrm{SO}_{3} \mathrm{Ph}$ or $\mathrm{SO}_{2} \mathrm{Ph}$ moieties. 
Table 2. In vitro antimalarial activity of Michael adducts of azaartemisinin

\begin{tabular}{|c|c|c|c|c|c|c|c|}
\hline $\mathrm{GWE}^{\prime}$ & 萻 & $\begin{array}{c}\text { In vitro } \\
\text { antimalaria } \\
\text { l activity } \\
\text { against the } \\
\text { W-2 clone } \\
\text { of } \\
\text { P. } \\
\text { falciparum }\end{array}$ & $\begin{array}{c}\text { In vitro } \\
\text { antimalaria } \\
\text { l activity } \\
\text { against the } \\
\text { D-6 clone } \\
\text { of } \\
\text { P. } \\
\text { falciparum }\end{array}$ & $\mathrm{GWE}^{-}$ & & $\begin{array}{c}\text { In vitro } \\
\text { antimalaria } \\
\text { l activity } \\
\text { against the } \\
\text { W-2 clone } \\
\text { of } P \text {. } \\
\text { falciparum }\end{array}$ & $\begin{array}{c}\text { In vitro } \\
\text { antimalaria } \\
\text { l activity } \\
\text { against the } \\
\text { D-6 clone } \\
\text { of } P \text {. } \\
\text { falciparum }\end{array}$ \\
\hline Compd & EWG & $\begin{array}{c}\mathrm{IC}_{50}(1) / \mathrm{IC}_{50} \\
(\mathrm{Compd}) \\
\end{array}$ & $\begin{array}{c}\mathrm{IC}_{50}(1) / \mathrm{IC}_{50} \\
(\mathrm{Compd})\end{array}$ & Compd & EWG & $\begin{array}{c}\mathrm{IC}_{50}(1) / \mathrm{IC}_{50} \\
(\mathrm{Compd})\end{array}$ & $\begin{array}{c}\mathrm{IC}_{50}(1) / \mathrm{IC}_{50} \\
(\mathrm{Compd})\end{array}$ \\
\hline 13a & $\mathrm{CO}_{2} \mathrm{Et}$ & 0.41 & 1.5 & $14 a$ & $\mathrm{CO}_{2} \mathrm{CH}_{3}(E)$ & 1.2 & 2.0 \\
\hline $13 b$ & $\mathrm{CN}$ & 0.43 & 1.3 & $14 b$ & $\mathrm{COCH}_{3}(E)$ & 1.25 & 2.54 \\
\hline $13 c$ & $\mathrm{SO}_{3} \mathrm{Ph}$ & 0.96 & 1.7 & $14 c$ & $\begin{array}{c}\mathrm{CON}\left(\mathrm{CH}_{3}\right)_{2} \\
(E)\end{array}$ & 0.35 & 0.39 \\
\hline 13d & $\mathrm{SO}_{2} \mathrm{Ph}$ & 0.32 & 1.1 & 14d & $\mathrm{CN}(Z)$ & 1.7 & 2.7 \\
\hline $13 e$ & $\mathrm{CO}_{2} \mathrm{C}\left(\mathrm{CH}_{3}\right)_{2}$ & 0.0012 & 0.03 & & & & \\
\hline $13 f$ & $\begin{array}{l}\mathrm{EtO}_{2} \mathrm{CCH}- \\
\mathrm{CH}_{2} \mathrm{CO}_{2} \mathrm{Et}\end{array}$ & 0.066 & 0.24 & & & & \\
\hline $13 g$ & $\mathrm{CO}_{2} \mathrm{CH}_{3}$ & 1.0 & 1.77 & & & & \\
\hline $13 h$ & $\mathrm{CH}_{2} \mathrm{OH}$ & 0.64 & 1.02 & & & & \\
\hline $13 \mathbf{i}$ & $\mathrm{CHO}$ & 0.18 & 0.49 & & & & \\
\hline $13 j$ & $\mathrm{COCH}_{3}$ & 3.0 & 3.2 & & & & \\
\hline 13k & $\mathrm{COPh}$ & 1.8 & 1.8 & & & & \\
\hline
\end{tabular}

\section{3. $N$-Amino and $N$-hydroxy-11-azaartemisinins}

In their pursuit to synthesize $N$-amino-11-azaartemisinins 15 , $\operatorname{Singh}^{12}$ used a modification of the method developed by Ziffer. ${ }^{3}$ They noticed that by switching the solvent from chloroform to a 7:3 methanol-chloroform mixture at $0{ }^{\circ} \mathrm{C}$ during the first step of the reaction, they could suppress formation of the deoxy analogue completely (Scheme 7). Reactions with hydroxylamine and 2aminoethanol could easily be performed by using the same method, affording hydroxy derivatives 16 and 17. 


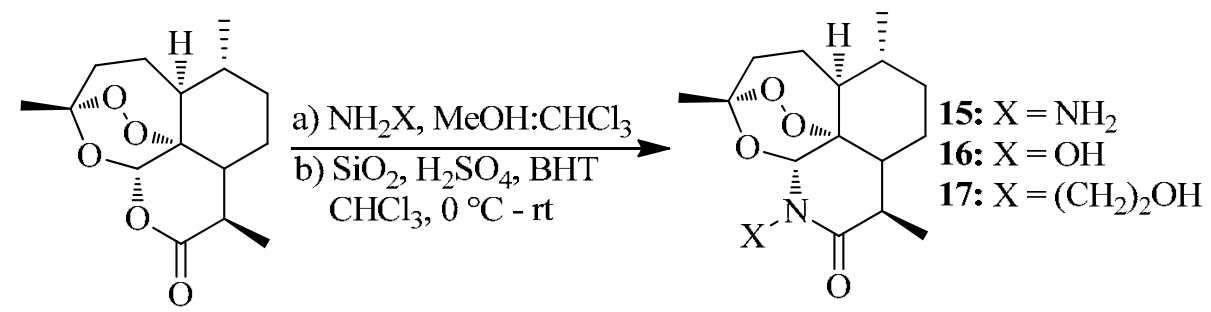

Scheme 7. Synthesis of $N$-amino and hydroxyl azaartemisinins.

The $\mathrm{N}$-amino azaartemisinins 15 presented the perfect scaffold for derivatisation with different functionalities (Table 3). Amide derivatives $\mathbf{1 8}$ were obtained in average to good yields (60-93\%) by reacting 15 with a series of acid chlorides in anhydrous benzene with triethylamine as base (Scheme 8). Also dimers were accessible, albeit in low yields (20-34\%), by reacting 2 eq of 15 with terephthaloyl chloride and oxalyl chloride respectively, under the same conditions. Treating 15 with benzaldehyd derivatives led to the corresponding imines 19, which are easily converted to amines $\mathbf{2 0}$ using conventional methods (sodium borohydride reduction).

Table 3. Amide, imine and amine derivatives

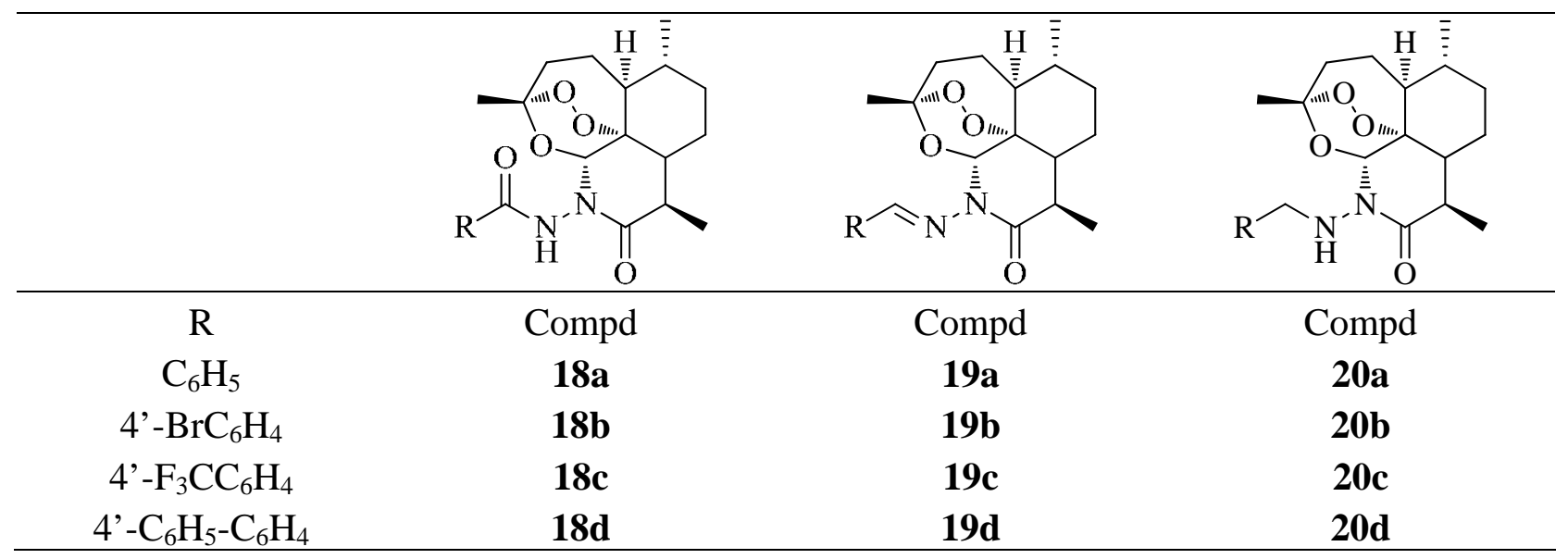




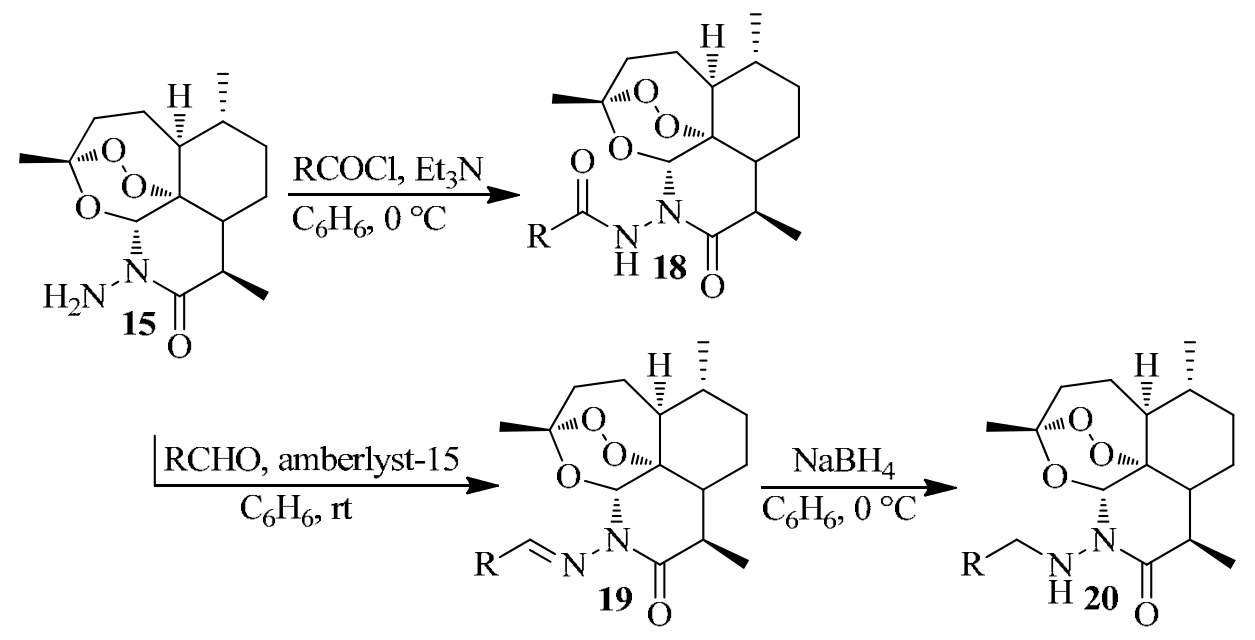

Scheme 8. Conversion of $\mathrm{N}$-amino azaartemisinin to amide, imines and amines.

Reaction of the deprotonated hydroxy azaartemisinins 16 and 17 with a range of alkyl bromides, furnished the corresponding ethers 21 and 22 in acceptible yields (60-74\%, Scheme 9, Table 4).

Table 4. Ether derivatives

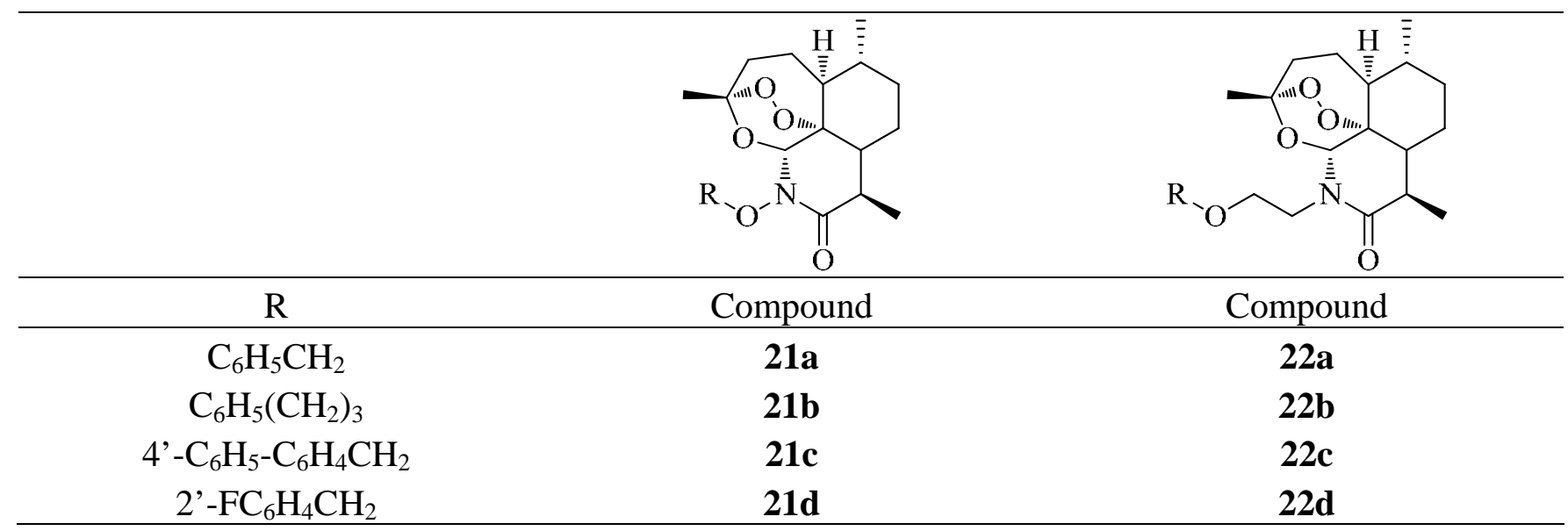

Although 15, 16 and 17 displayed poor antimalarial activity in vivo against $P$. yoelii in mice (Table 5; oral administration), some derivatives showed very promising results (most notably 18d, 20d and 21a). 


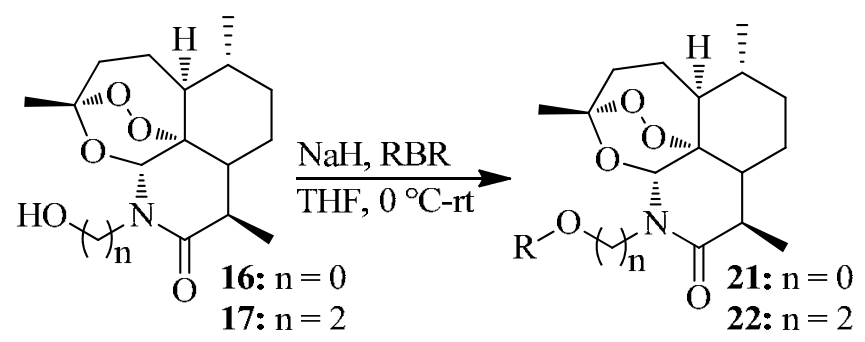

Scheme 9. Conversion of hydroxy azaartemisinin into ether derivatives.

Table 5. In vivo antimalarial activity of selected $N$-amino and $N$-hydroxy against $P$. yoelii in mice

\begin{tabular}{cccc}
\hline Compd & $\begin{array}{c}\text { Oral dose } \\
(\mathrm{mg} / \mathrm{kg} \mathrm{x} \text { 4 days })\end{array}$ & $\begin{array}{c}\text { \% suppresion of } \\
\text { parasitaemia on day } 4\end{array}$ & \# mice survived \\
\hline $\mathbf{1 5}$ & 24 & 100 & $2 / 5$ \\
$\mathbf{1 6}$ & 48 & 78.11 & $0 / 5$ \\
$\mathbf{1 7}$ & 48 & 100 & $0 / 5$ \\
$\mathbf{1 8 d}$ & 12 & 100 & $5 / 5$ \\
& 6 & 94.37 & $0 / 5$ \\
$\mathbf{2 0 d}$ & 12 & 100 & $5 / 5$ \\
& 6 & 100 & $1 / 5$ \\
$\mathbf{2 1 a}$ & 24 & 100 & $5 / 5$ \\
& 12 & 100 & $2 / 5$ \\
\multirow{4}{4}{} & 48 & 100 & $5 / 5$ \\
& 24 & 100 & $1 / 5$ \\
\hline
\end{tabular}

\section{4. $N$-sulfonyl and $N$-carbonyl-11-azaartemisinins}

In an attempt to improve the thermal stability, and thus the shelf life storage in tropical countries where malaria is prevalent, $N$-sulfonyl and $N$-carbonyl azaartemisinins were recently prepared by the group of Haynes. ${ }^{8}$

Initial attempts to prepare the $N$-sulfonyl derivatives by treatment of the lactam $\mathbf{6 a}$ with methanesulfonyl chloride or methanesulfonic anhydride in the presence of amine bases were unsuccessful. However, by switching to LDA in THF at $-78{ }^{\circ} \mathrm{C}$, 23a could be obtained in a satisfactory $62 \%$ yield (Scheme 10 ). Sodium hydride in THF at $0{ }^{\circ} \mathrm{C}$ gave similar results (55\% yield). The structure of 23a was confirmed by single-crystal X-ray analysis. The same conditions could be adapted to build a small library. Aliphatic sulfonyl chlorides gave better yields than their aromatic counterparts. Moreover, Haynes et al. managed to obtain the dimer 23u (through reaction with biphenyl-4,4'-disulfonyl chloride), albeit in low yield (7\%). No product could be isolated from reaction with benzene-1,3-disulfonyl chloride though. 


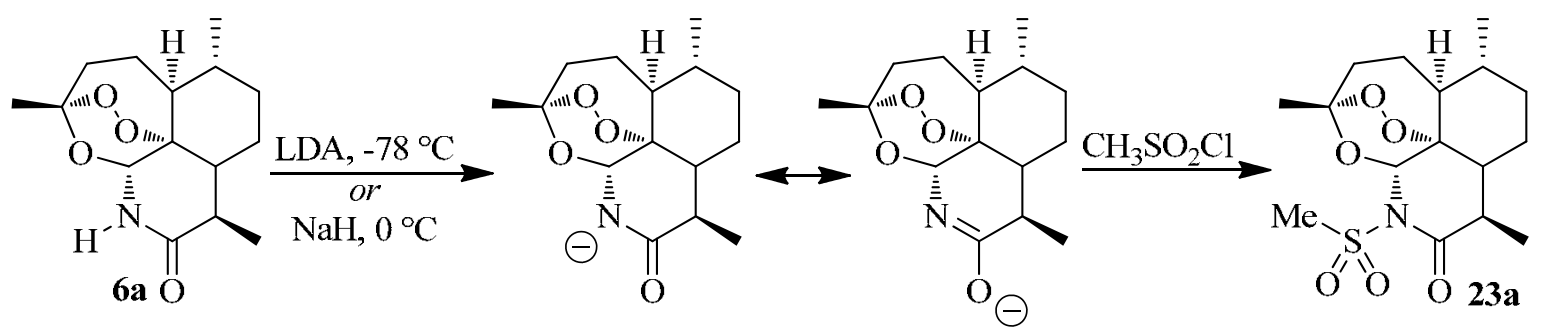

Scheme 10. Synthesis of $N$-sulfonyl azaartemisinins.

This methodology also proved successful in the synthesis of $N$-carbonyl derivatives 24, by treating the deprotonated 11-azaartemisinin 6a with acyl chlorides (Structure block 2). It is important to note that reaction exclusively took place at the nitrogen atom. Dimeric adducts 24f-i were obtained from diacid chlorides in low to moderate yields (13-35\%). Finally, even acylureas 25 were accessible by this method through reaction of the deprotonated azaartemisinin $\mathbf{6 a}$ with aryl isocyanates. A summary of all the products can be found in Table 6. Especially the $N$ sulfonyl compounds $\mathbf{2 3}$ possessed some desirable properties: they were nicely crystalline and much more thermally stable than the clinically used artemisinins DHA, artemether and artesunate. Moreover, they showed no sign of degradation during storage at room temperature for periods of well over 3 years.

In a next step, Haynes et al. attempted to reduce the carbonyl group of azaartemisinin $\mathbf{6 a}$ (Scheme 11). Test reactions using common reagents to reduce amides to amines, or to convert artemisinin into 10-deoxo derivatives were unsuccessful. Even for 23a with an electron withdrawing group this reaction failed. Treatment of 23a in DCM and an excess of trimethylsilyl chloride with lithium borohydride caused isomerization to 26 and 27. Reduction of 23a with excess diisobutyl aluminium hydride (DIBAL) in DCM yielded the crystalline alcohol 28 (22\%). However, it was not possible to remove the hydroxy group. Compounds 27 and 28 were unambiguously characterized by X-ray analysis.

The compounds in this study possess relatively low cytotoxicity. Several of the arylsulfonyl derivatives have antimalarial activity comparable with artesunate against the drug-sensitive 3D7 clone of the NF54 isolate and the multidrug-resistant Thailand K1 strain of $P$. falciparum (Table 6). In general, the $N$-carbonyl derivatives 24 surpass the $N$-sulfonyls 23 as antimalarials. The

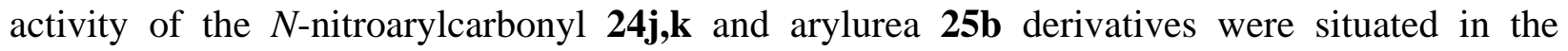
subnanogram $/ \mathrm{ml}$ range. However, despite log $\mathrm{P}$ values below 3.5, most of the compounds were poorly soluble in water (in sharp contrast with $\mathbf{6 a}$, that has a solubility at $\mathrm{pH} 7 \mathrm{of}>1000 \mathrm{mg} / \mathrm{L}$ ). 

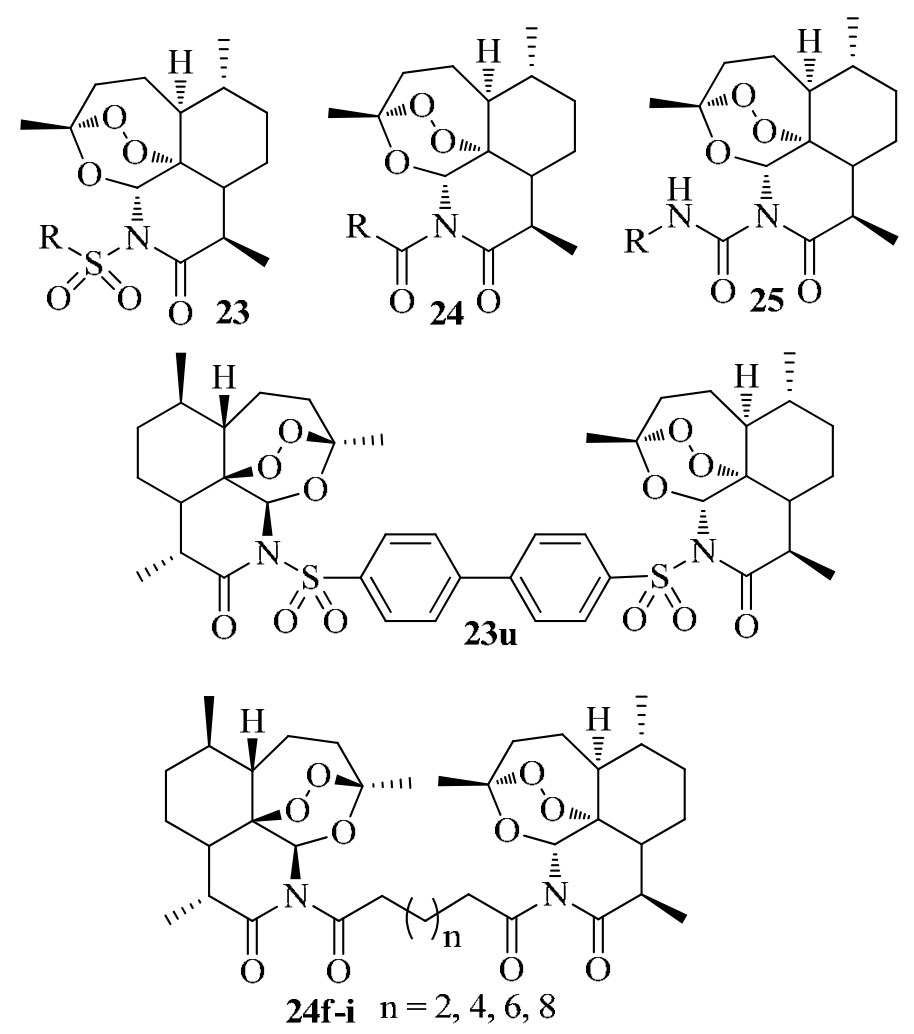

Structure block 2. $N$-sulfonyl and carbonyl azaartemisinins.

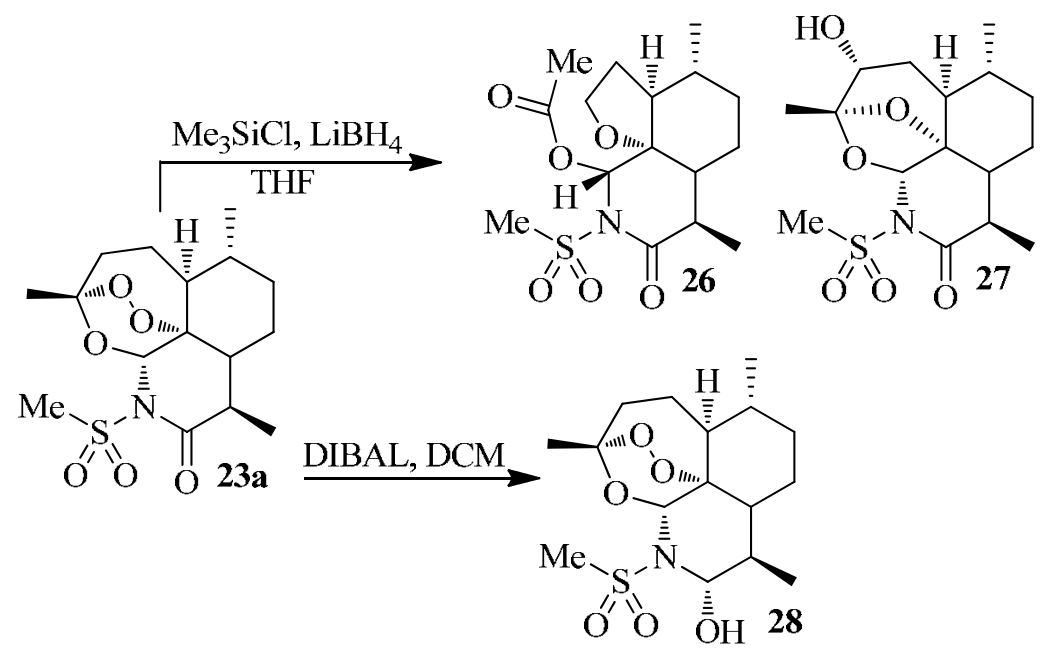

Scheme 11. Attempts at reduction of the lactam carbonyl group. 
Table 6. In vitro antimalarial activity of $N$-sulfonyl, carbonyl and acylurea derivatives

\begin{tabular}{|c|c|c|c|c|c|c|c|}
\hline $\mathrm{O}^{\mathrm{R}} \mathrm{i}$ & $\|_{O}$ & $\begin{array}{c}\text { In vitro } \\
\text { antimalarial } \\
\text { activity } \\
\text { against the } \\
\text { 3D7 strain } \\
\text { of } P \text {. } \\
\text { falciparum }\end{array}$ & $\begin{array}{c}\text { In vitro } \\
\text { antimalarial } \\
\text { activity } \\
\text { against the } \\
\text { K1 strain of } \\
P . \\
\text { falciparum }\end{array}$ & J & 0 & $\begin{array}{c}\text { In vitro } \\
\text { antimalarial } \\
\text { activity } \\
\text { against the } \\
\text { 3D7 strain } \\
\text { of } P \text {. } \\
\text { falciparum }\end{array}$ & $\begin{array}{c}\text { In vitro } \\
\text { antimalarial } \\
\text { activity } \\
\text { against the } \\
\text { K1 strain of } \\
P . \\
\text { falciparum } \\
\end{array}$ \\
\hline Compd & $\mathrm{R}$ & $\begin{array}{c}\mathrm{IC}_{50} \\
{[\mathrm{ng} / \mathrm{ml}(\mathrm{nM})]}\end{array}$ & $\begin{array}{c}\mathrm{IC}_{50} \\
{[\mathrm{ng} / \mathrm{ml}(\mathrm{nM})]}\end{array}$ & Compd & $\mathrm{R}$ & $\begin{array}{c}\mathrm{IC}_{50} \\
{[\mathrm{ng} / \mathrm{ml}(\mathrm{nM})]}\end{array}$ & $\begin{array}{c}\mathrm{IC}_{50} \\
{[\mathrm{ng} / \mathrm{ml}(\mathrm{nM})]}\end{array}$ \\
\hline $23 a$ & $\mathrm{CH}_{3}$ & $41.1(11.4)$ & $3.2(8.9)$ & $24 a$ & $\mathrm{CH}_{3}$ & $3.0(9.3)$ & 4.5 (13.9) \\
\hline $23 b$ & $\mathrm{CH}_{3} \mathrm{CH}_{2}$ & $1.7(4.6)$ & 3.7 (9.9) & $24 b$ & $\mathrm{CH}_{3} \mathrm{CH}_{2}$ & $2.0(5.9)$ & $1.0(3.0)$ \\
\hline $23 c$ & $\mathrm{CH}_{3}\left(\mathrm{CH}_{2}\right)_{2}$ & I & I & $24 c$ & $\mathrm{CH}_{3}\left(\mathrm{CH}_{2}\right)_{2}$ & $2.0(5.7)$ & $2.0(5.7)$ \\
\hline 23d & $\mathrm{CH}_{3}\left(\mathrm{CH}_{2}\right)_{7}$ & $1.1(2.4)$ & $2.1(4.6)$ & 24d & $\mathrm{CH}_{3}\left(\mathrm{CH}_{2}\right)_{5}$ & $1.0(2.6)$ & $2.0(5.3)$ \\
\hline $23 e$ & $\mathrm{CH}_{3}\left(\mathrm{CH}_{2}\right)_{15}$ & l & 50 & $24 e$ & $\mathrm{CH}_{3}\left(\mathrm{CH}_{2}\right)_{14}$ & $>50$ & $>50$ \\
\hline $23 f$ & $4^{\prime}-\mathrm{FC}_{6} \mathrm{H}_{4}$ & l & $8.0(18.2)$ & $24 f$ & $-\left(\mathrm{CH}_{2}\right)_{4^{-}}$ & $2.3(3.4)$ & $50(74.3)$ \\
\hline $23 g$ & $4^{\prime}-\mathrm{ClC}_{6} \mathrm{H}_{4}$ & $>50$ & 17 & $24 g$ & $-\left(\mathrm{CH}_{2}\right)_{6}{ }^{-}$ & $9.2(13.1)$ & $9.0(12.8)$ \\
\hline $23 \mathrm{~h}$ & $4^{\prime}-\mathrm{BrC}_{6} \mathrm{H}_{4}$ & $>50$ & $>50$ & $24 h$ & $-\left(\mathrm{CH}_{2}\right)_{8^{-}}$ & $13(17.8)$ & $2.0(2.7)$ \\
\hline $23 \mathbf{i}$ & $4^{\prime}-\mathrm{CH}_{3} \mathrm{C}_{6} \mathrm{H}_{4}$ & $>50$ & 37 & $24 i$ & $-\left(\mathrm{CH}_{2}\right)_{10^{-}}$ & $>50$ & 40 \\
\hline $23 \mathbf{j}$ & $4^{\prime}-\mathrm{O}_{2} \mathrm{NC}_{6} \mathrm{H}_{4}$ & 17.1 & 9.1 (19.5) & $24 j$ & $4^{\prime}-\mathrm{O}_{2} \mathrm{NC}_{6} \mathrm{H}_{4}$ & $0.45(1.0)$ & $0.6(1.4)$ \\
\hline $23 \mathbf{k}$ & $3^{\prime}-\mathrm{O}_{2} \mathrm{NC}_{6} \mathrm{H}_{4}$ & $2.1(4.5)$ & $2.2(4.7)$ & $24 k$ & $3^{\prime}-\mathrm{O}_{2} \mathrm{NC}_{6} \mathrm{H}_{4}$ & $0.46(1.1)$ & $0.6(1.4)$ \\
\hline 231 & $2^{\prime}-\mathrm{O}_{2} \mathrm{NC}_{6} \mathrm{H}_{4}$ & l & $10(21.4)$ & 241 & $\begin{array}{c}3^{\prime}, 5^{\prime}- \\
\left(\mathrm{O}_{2} \mathrm{~N}\right)_{2} \mathrm{C}_{6} \mathrm{H}_{3}\end{array}$ & / & $2.0(4.2)$ \\
\hline $23 m$ & $3 ”-\mathrm{NCC}_{6} \mathrm{H}_{4}$ & I & $>50$ & & & & \\
\hline $23 n$ & $\begin{array}{l}\text { 4'-Cl-3'- } \\
\mathrm{O}_{2} \mathrm{NC}_{6} \mathrm{H}_{4}\end{array}$ & $1.5(3.0)$ & $3.8(7.6)$ & & & & \\
\hline 230 & $\begin{array}{c}3^{\prime}, 4^{\prime}- \\
\left(\mathrm{CH}_{3} \mathrm{O}\right)_{2} \mathrm{C}_{6} \\
\mathrm{H}_{3}\end{array}$ & $>50$ & 40 & $\kappa$ & & & \\
\hline & 4’- & & & & $\mathrm{O}$ & & \\
\hline $23 p$ & $\begin{array}{c}\mathrm{CH}_{3} \mathrm{SO}_{2} \mathrm{C}_{6} \\
\mathrm{H}_{4}\end{array}$ & I & $13(26)$ & & & & \\
\hline $23 q$ & $\begin{array}{c}4^{\prime}-\mathrm{C}_{6} \mathrm{H}_{5^{-}} \\
\mathrm{C}_{6} \mathrm{H}_{4}\end{array}$ & 40 & 45 & Compd & $\mathrm{R}$ & & \\
\hline $23 r$ & $\begin{array}{l}\text { 5'-Cl-2'- } \\
\text { thienyl }\end{array}$ & / & 40 & $25 a$ & $\mathrm{C}_{6} \mathrm{H}_{5} \mathrm{NH}$ & / & l \\
\hline 23s & 2-naphthyl & $2.8(5.9)$ & $0.2(0.42)$ & $25 b$ & $\begin{array}{c}4- \\
\mathrm{O}_{2} \mathrm{NC}_{6} \mathrm{H}_{4} \mathrm{NH} \\
\end{array}$ & $0.6(1.3)$ & $0.4(0.9)$ \\
\hline
\end{tabular}


Table 6. Continued

\begin{tabular}{|c|c|c|c|}
\hline & & $\begin{array}{c}\text { In vitro } \\
\text { antimalarial } \\
\text { activity } \\
\text { against the } \\
3 \mathrm{D} 7 \text { strain } \\
\text { of } P \text {. } \\
\text { falciparum }\end{array}$ & $\begin{array}{c}\text { In vitro } \\
\text { antimalarial } \\
\text { activity } \\
\text { against the } \\
\text { K1 strain of } \\
P \text {. } \\
\text { falciparum }\end{array}$ \\
\hline Compd & $\mathrm{R}$ & $\begin{array}{c}\mathrm{IC}_{50} \\
{[\mathrm{ng} / \mathrm{ml}(\mathrm{nM})]}\end{array}$ & $\begin{array}{c}\mathrm{IC}_{50} \\
{[\mathrm{ng} / \mathrm{ml}(\mathrm{nM})]}\end{array}$ \\
\hline $23 t$ & 5'-dansyl & I & I \\
\hline $23 u$ & $\begin{array}{c}\text { 8'- } \\
\text { quinolinyl }\end{array}$ & $1.9(4.0)$ & $2.0(4.2)$ \\
\hline $23 v$ & $\begin{array}{l}\text { bis-4',4”- } \\
\text { biphenyl }\end{array}$ & I & I \\
\hline 5 & I & 1.5 (3.9) & $2.2(5.7)$ \\
\hline
\end{tabular}

\section{5. $N$-Biotinylated azaartemisinin derivatives}

As the exact mechanism of artemisin remains under debate till this date, Meng and Yao decided to couple artemisinin with biotin through a series of linkers, in order to develop a small molecular probe. ${ }^{13}$ Indeed, the biotin-avidin system has often been used to identify the target proteins of a substrate. Building on the work of Singh and co-workers, ${ }^{12}$ their group synthesized the azaartemisines $\mathbf{6 j}$ and $\mathbf{1 5}$ (Structure block 3). In a next step the molecular probe could be assembled by coupling either D-biotin itself, or a biotinylated triethylene glycol spacer $\mathbf{2 9}$ with terminal carboxylic acid function, with the free amine function of the azaartemisin derivatives $\mathbf{6 j}$ and 15 (Structure block 4). The condensation furnished the desired products $\mathbf{3 0}$ and $\mathbf{3 1}$ in good yield (55-65\%) by using standard reagents for amide bond formation (EDCI, HOBT) in DMF as solvent and triethylamine as base.

The resulting biotinylated artemisinin derivatives showed poor in vitro anti-tumor activity against the HCT-116 human colon carcinoma cell line. Furthermore, solubility of the samples in the bioassay presented a serious problem at higher concentrations.

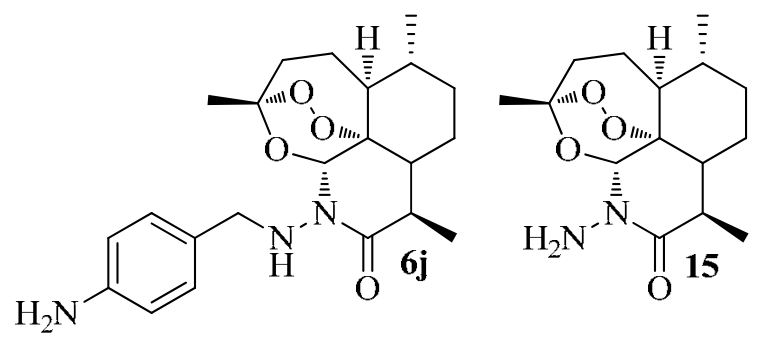

Structure block 3. Azaartemisinins with free primary amine function. 


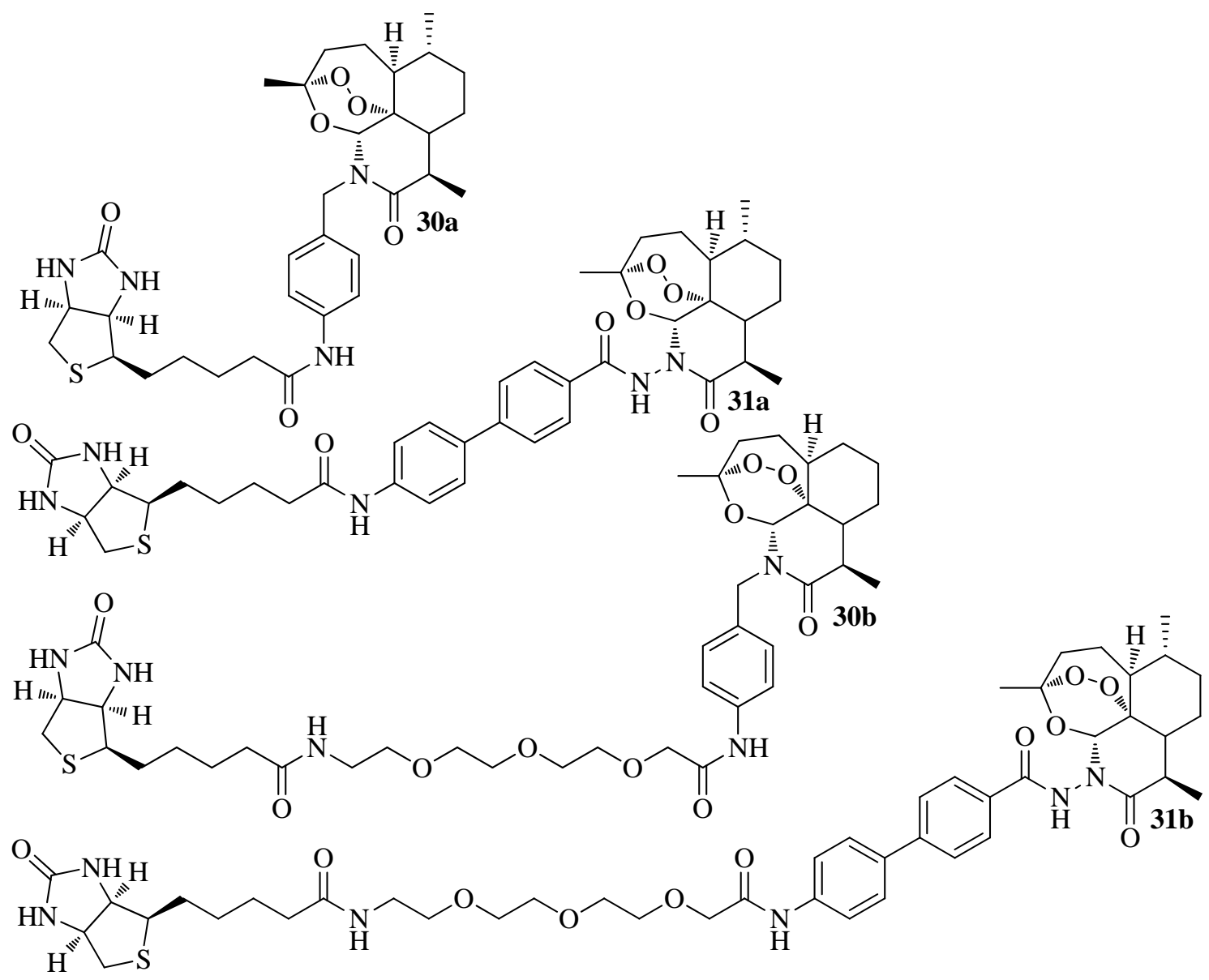

Structure block 4. Biotinylated artemisnin derivatives.

\subsection{1-Azaartemisinin desoxo derivatives}

El-Feraly et al. investigated the reaction of artemisinin with ethanolamine. ${ }^{14}$ After chromatography of the crude reaction mixture, the desoxo azaartemisinin $\mathbf{7 k}$ was isolated (Structure block 5). However, when the crude residue was crystallized from a $n$-hexane/ether mixture instead of purifying with column chromatography, the intermediate 32 could be identified as the sole product. Though this intermediate had been postulated, it had never before been isolated or characterized. The primary alcohol group of the lactam tether could easily be acylated to 33. Neither 7k or 33 showed any activity in the antimalarial testing (Table 7); diol 32 however, was found to be cytotoxic to human breast ductal carcinoma.

Reaction of artemisinin in a methanolic solution of ethylenediamine afforded the symmetrical desoxodimer $\mathbf{3 4}$ in almost quantitative yield. It is noteworthy that this compound, though lacking the endoperoxide function, nevertheless surprisingly exhibited approximately the same antimalarial activity against the D-6 and W-2 strain of $P$. falciparum as artemisinin. 
In 2005, the group of Galal tested the antifungal acivity of $\mathbf{7 k}$ and $\mathbf{3 4}$ against Cryptococcus neoformans and Candida albicans. ${ }^{15}$ Both compounds were completely inactive, which was attributed to the lack of the endoperoxide function.

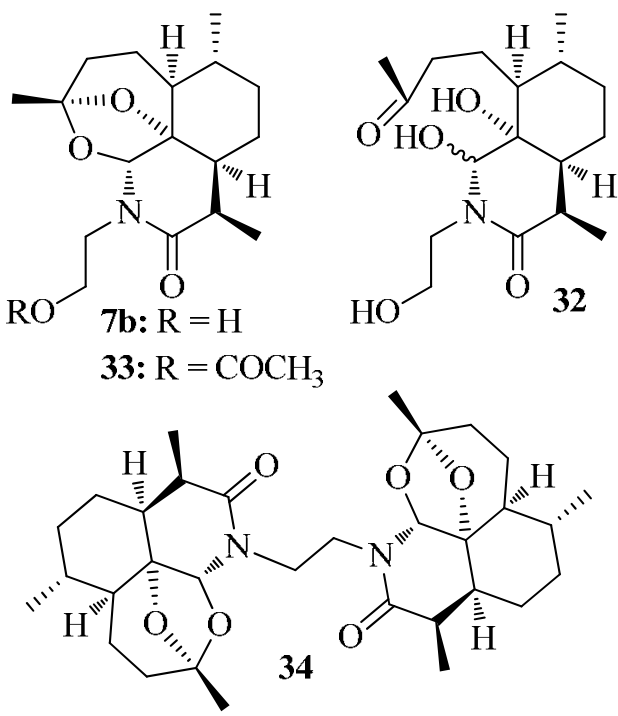

Structure block 5. Desoxo 11-azaartemisinins.

Table 7. In vitro antimalarial activity of desoxo 11-azaartemisinins

\begin{tabular}{ccc}
\hline & $\begin{array}{c}\text { In vitro antimalarial activity against } \\
\text { the D-6 clone of } P \text {. falciparum }\end{array}$ & $\begin{array}{c}\text { In vitro antimalarial activity against } \\
\text { the W-2 clone of } P \text {. } \text { falciparum }^{b}\end{array}$ \\
\hline Compd & $\mathrm{IC}_{50}[\mathrm{ng} / \mathrm{ml}(\mathrm{nM})]$ & $\mathrm{IC}_{50}[\mathrm{ng} / \mathrm{ml}(\mathrm{nM})]$ \\
\hline $\mathbf{7 k}$ & $/(>400)$ & $/(>400)$ \\
$\mathbf{3 2}$ & $/(>400)$ & $/(>400)$ \\
$\mathbf{3 4}$ & $12.0(21.6)$ & $8.7(15.6)$ \\
$\mathbf{1}$ & $6-10(21.3-35.5)$ & $6-10(21.3-35.5)$ \\
\hline
\end{tabular}

In the course of their study on the $\mathrm{Fe}^{2+}$-mediated decomposition of artemisinin derivatives, the group of Haynes isolated the desoxo enamines 35a and 35b as part of the reduction products of 36a and 36b respectively (Structure block 6). ${ }^{16}$ Enamine 35a could be converted to the corresponding hydroxy lactam $\mathbf{3 7}$ by treating it with ruthenium trichloride/sodium periodate. 


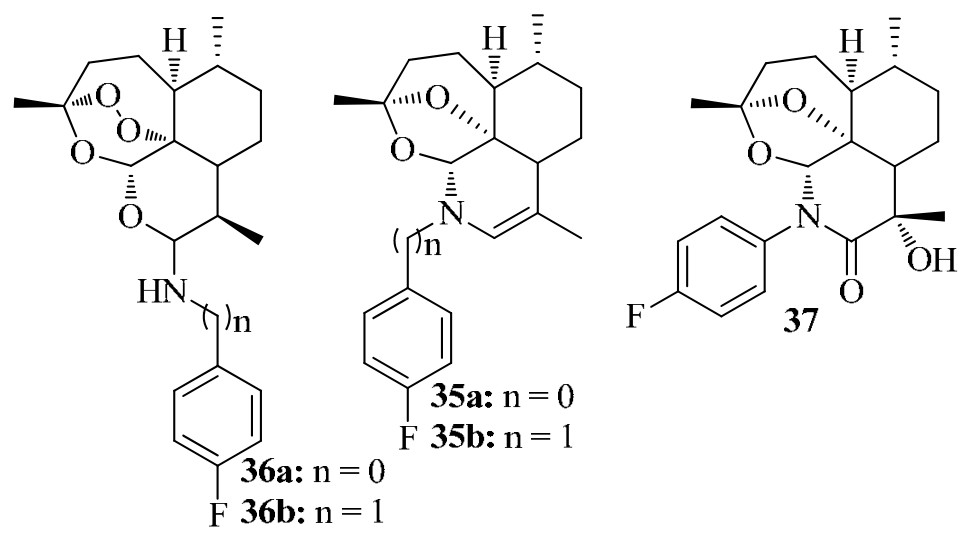

Structure block 6. Desoxo enamines and azaartemisinin.

\subsection{1-Aza-9-desmethylartemisinins}

The group of Avery synthesized a number of aza-desmethylartemisinins $\mathbf{3 8},{ }^{\mathbf{1 7}}$ as a late synthetic precursor 39 was readily available from their artemisinin total synthesis project (Scheme 12). ${ }^{4}$ Carboxylic acid 39 was converted to the corresponding mixed anhydride with ethyl chloroformate. Subsequent condensation with the appropriate primary amines led to ketal amides that were converted into the desired products in $20-65 \%$ yield by exposure to ozone and acidcatalyzed cyclization. The analogs were tested in vitro in parasitized whole blood (humans) against two strains of $P$. falciparum, the chloroquine-resistant (and mefloquine-sensitive) Indochina W-2 clone and the chloroquine-sensitive (and mefloquine resistant) Sierra Leone D-6 clone respectively (Table 8). Most of these analogs were also tested in vivo against both strains. In order to gain a better understanding of the SAR involved, the log P values for the majority of these compounds were determined, using known procedures. No correlation was found between $\log \mathrm{P}$ and the activity, whether in vivo or in vitro. Although removal of the C-9 methyl of artemisinin improves the activity about 6 -fold, ${ }^{18}$ the same trend was not observed for the azaartemisinins. In general, the 11-azaartemisinins proved to be approximately as active as artemisinin, although it is noteworthy to point out that the $N$-methyl analog 38a (Table 8) was more than 5 times as potent as artemisinin in the resistant $\mathrm{W}-2$ strain.

Dayan et al. investigated the phytotoxicity of a number of known artemisin analogues, including some aza derivatives (Table 9) ${ }^{19}$ Derivative 38d was the only aza compound more potent than artemisinin. It is worth mentioning that, although the other azaartemisinins were less active than artemisinin, they were the only products that showed some selectivity, being more toxic against Lolium than to Lactuca or Arabidopsis. The decreased activity of these derivatives could be explained by the fact that they bear large hydrophobic moieties, that may cause poor uptake by plants. 


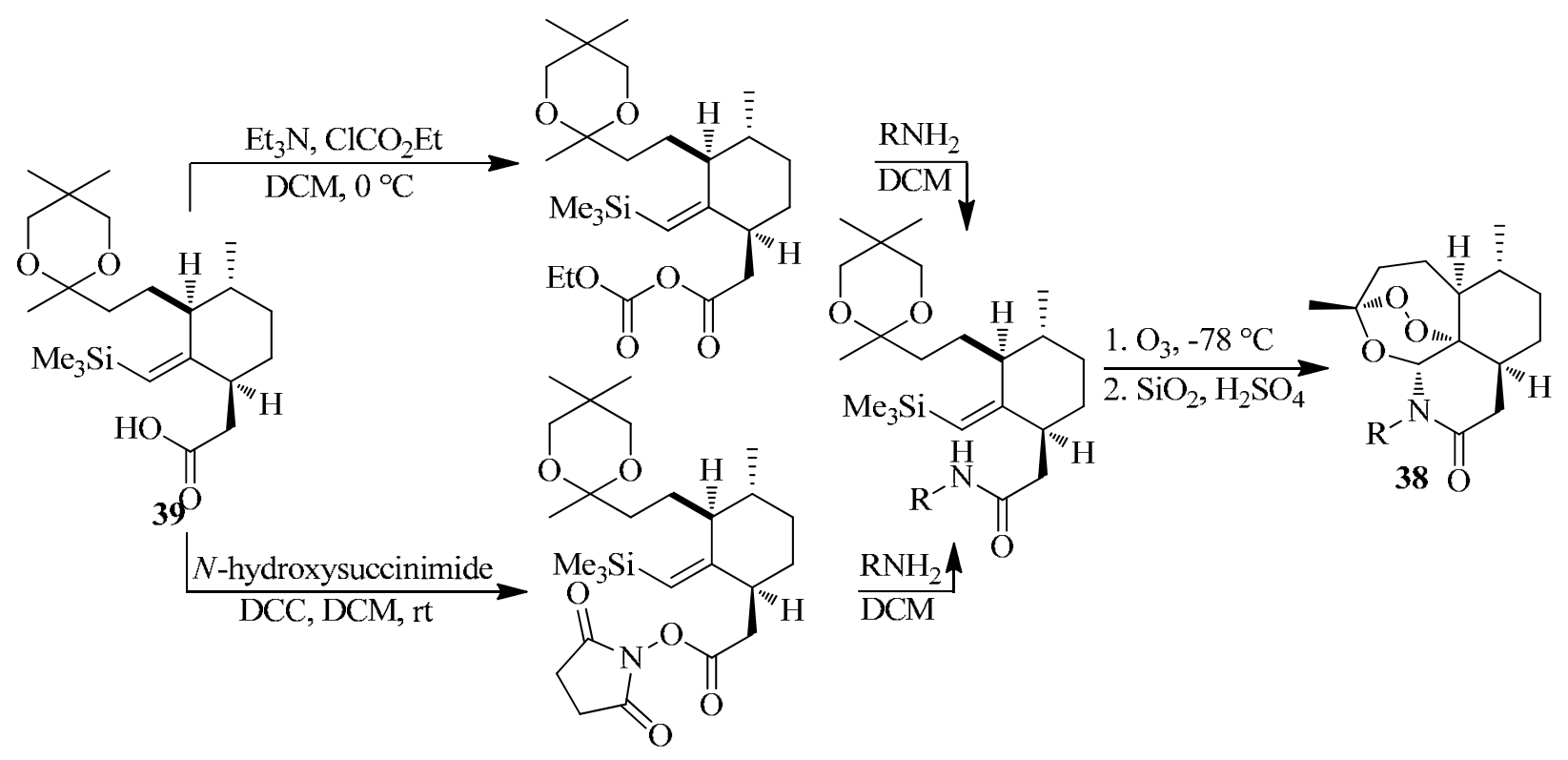

Scheme 12. 11-Aza-9-desmethylartemisinins.

Table 8. In vitro anti-malarial activity of 11-aza-9-desmethylartemisinins

\begin{tabular}{|c|c|c|c|}
\hline & & $\begin{array}{l}\text { In vitro antimalarial } \\
\text { activity against the } \mathrm{W}-2 \\
\text { clone of } P \text {. falciparum }\end{array}$ & $\begin{array}{l}\text { In vitro antimalarial } \\
\text { activity against the D-6 } \\
\text { clone of } P \text {. falciparum }\end{array}$ \\
\hline Compd & $\mathrm{R}$ & $\begin{array}{c}\mathrm{IC}_{50}(1) / \mathrm{IC}_{50}(\mathrm{Compd}) \\
\mathrm{x} \mathrm{MW(Compd)/MW} \mathrm{(1)}\end{array}$ & $\begin{array}{c}\mathrm{IC}_{50}(1) / \mathrm{IC}_{50}(\mathrm{Compd}) \\
\mathrm{x} \mathrm{MW}(\mathrm{compd}) / \mathrm{MW}(1)\end{array}$ \\
\hline $38 a$ & $\mathrm{CH}_{3}$ & 5.00 & 2.13 \\
\hline $38 b$ & $\mathrm{CH}_{3}\left(\mathrm{CH}_{2}\right)_{2}$ & 1.11 & 0.75 \\
\hline $38 c$ & $\mathrm{C}_{4} \mathrm{H}_{9}(i)$ & 1.05 & 1.45 \\
\hline 38d & $\mathrm{C}_{5} \mathrm{H}_{11}(n)$ & 0.63 & 1.10 \\
\hline $38 \mathrm{e}$ & $\mathrm{C}_{5} \mathrm{H}_{11}(\mathrm{i})$ & 0.92 & 1.49 \\
\hline $38 f$ & $\left(\mathrm{CH}_{3}\right)_{2} \mathrm{NCH}_{2} \mathrm{CH}_{2}$ & / & 0.37 \\
\hline $38 \mathrm{~g}$ & $\mathrm{HO}_{2} \mathrm{CCH}_{2}$ & / & 0.06 \\
\hline $38 \mathrm{~h}$ & $\mathrm{HO}_{2} \mathrm{C}\left(\mathrm{CH}_{2}\right)_{5}$ & 0.02 & 0.12 \\
\hline $38 \mathrm{i}$ & $\left(\mathrm{CH}_{3}\right)_{3} \mathrm{CO}_{2} \mathrm{CCH}_{2}$ & / & / \\
\hline $38 \mathbf{j}$ & $\mathrm{C}_{6} \mathrm{H}_{5} \mathrm{CH}_{2}$ & 2.17 & 1.89 \\
\hline $38 \mathbf{k}$ & $p-\mathrm{ClC}_{6} \mathrm{H}_{4} \mathrm{CH}_{2}$ & 0.69 & 1.11 \\
\hline 381 & $\mathrm{C}_{6} \mathrm{H}_{5}\left(\mathrm{CH}_{2}\right)_{2}$ & 1.43 & 1.97 \\
\hline $38 \mathrm{~m}$ & $\mathrm{C}_{6} \mathrm{H}_{5}\left(\mathrm{CH}_{2}\right)_{3}$ & 1.05 & 2.05 \\
\hline
\end{tabular}


Table 9. Phytotoxicity of selected 11-aza-9-desmethylartemisinins

\begin{tabular}{|c|c|c|c|c|c|c|c|c|}
\hline Compd & \multicolumn{2}{|c|}{ Concentration } & \multicolumn{2}{|c|}{ Root inhibition \% } & \multicolumn{2}{|c|}{ Seed germination score } & \multicolumn{2}{|c|}{ Herbicidal activity } \\
\hline & $(\mathrm{mg} / \mathrm{ml})$ & $(\mu \mathrm{M})$ & Lactuca & Lolium & Arabidopsis & Lactuca $^{a}$ & Lolium $^{a}$ & Arabidopsis $^{b}$ \\
\hline \multirow{3}{*}{$38 c$} & 0.001 & 3 & 68 & 81 & 4.5 & - & - & - \\
\hline & 0.01 & 30 & 100 & 100 & 0.0 & + & + & + \\
\hline & 0.1 & 300 & 100 & 100 & 0.0 & + & + & + \\
\hline \multirow{3}{*}{ 38d } & 0.001 & 3 & 0 & 15 & 5.0 & - & - & - \\
\hline & 0.01 & 30 & 31 & 62 & 5.0 & - & - & - \\
\hline & 0.1 & 300 & 33 & 100 & 0.0 & - & - & + \\
\hline \multirow{3}{*}{381} & 0.001 & 2.7 & 0 & 43 & 5.0 & - & - & - \\
\hline & 0.01 & 27 & 0 & 100 & 5.0 & - & - & - \\
\hline & 0.1 & 270 & 16 & 100 & 2.0 & - & + & +- \\
\hline \multirow{3}{*}{$38 \mathrm{~m}$} & 0.001 & 2.6 & 0 & 0 & 5.0 & - & - & - \\
\hline & 0.01 & 26 & 0 & 32 & 4.0 & - & - & - \\
\hline & 0.1 & 260 & 0 & 90 & 0.0 & - & + & + \\
\hline
\end{tabular}

${ }^{a}$ Activity based upon Lactuca and Lolium root inhibition: high (+) 85-100\%, moderate (+-) 7085\%, no activity (-) $<70 \%$; ${ }^{b}$ Activity based upon Arabidopsis seed germination score: high (+) 01 (0-20\% germination), moderate (+-) 1-2 (20-40\% germination), no activity (-) 2-5 (40-100\% germination).

\section{Conclusions}

In this review, we tried to give a comprehensive overview of the synthesis, reactions and biological activity of 11-azaartemisinins and their derivatives, including the desoxo analogues.

The acid labile lactone function of artemisinin can be transformed into a more stable lactam through a sequence that consists of opening the lactone with ammonia or primary amines (including alkyl-, allyl-, aromatic or heteroaromatic amines, hydrazine or hydroxylamine), followed by closing the resulting amide under acidic conditions to restore the tetracyclic core. These scaffolds can be further converted into the corresponding alkyl, carbonyl, imine , amine, ether, sulfonyl and acylurea derivatives, etc.

Besides the azaartemisinins originating from artemisinin, 9-desmethyl derivatives are synthetically accessible by elaborating on a precursor that was previously used for the total synthesis of artemisinin.

The biological activity (in vitro and in vivo) of the azaartemisinins indicates their importance as potential drug candidates, most notably as antimalarials. 
Noteworthy is the report of a compound with aldehyd function in $\beta$-position of the nitrogen atom, which was 26 times more active in vitro (against $P$. falciparum) and 4 times more active in vivo (against $P$. berghei in mice) than artemisinin.

Therefore, it is really astonishing and incomprehensible that this group of compounds has received so little attention until now.

We can only hope that this review will contribute to give these 'neglected' artemisinin derivatives the appreciation they deserve. Certainly there remains a lot to be explored...

\section{Acknowledgements}

The authors thank the K. U. Leuven, the F.W.O. (NAFOSTED grant) and the "Ministerie voor Wetenschapsbeleid” for continuing financial support.

\section{References}

1. Tu, Y. Chin. Med. J. (Engl) 1999, 112, 976.

2. Attaran, A.; Barnes, K. I.; Curtis, C. Lancet 2004, 363, 237.

3. Torok, D. S.; Ziffer, H. Tetrahedron Lett. 1995, 36, 829.

4. Avery, M. A.; Chong, W. K. M.; Jennings-White, C. J. J. Am. Chem. Soc. 1992, 114, 974.

5. Torok, D. S.; Ziffer, H. J. Med. Chem. 1995, 38, 5045.

6. Galal, A. M.; Ahmad, M. S.; El-Feraly, F. S.; McPhail, A. T. J. Nat. Prod. 1999, 62, 54.

7. Haynes, R. K.; Pai, H. H.-O.; Voerste, A. Tetrahedron Lett. 1999, 40, 4715.

8. Haynes, R. K.; Wong, H.-N.; Lee, K.-W.; Lung, C.-M.; Shek, L. Y.; Williams, I. D.; Croft, S. L.; Vivas, L.; Rattray, L.; Stewart, L.; Wong, V. K. W.; Ko, B. C. B. Chem. Med. Chem. 2007, 2, 1464.

9. Mekonnen, B.; Ziffer, H. Tetrahedron Lett. 1997, 38, 731.

10. Katz, E.; Ma, J.; Kyle, D.; Ziffer, H. Bioorg. Med. Chem. Lett. 1999, 9, 2969.

11. Mekonnen, B.; Weiss, E.; Katz, E.; Ma, J.; Ziffer, H.; Kyle, D. E. Bioorg. Med. Chem. 2000, 8, 1111.

12. Singh, A. S.; Verma, V. P.; Hassam, M.; Krishna, N. N.; Puri, S. K.; Singh, C. Org. Lett. 2008, 10, 5461.

13. Pan, Q. Y.; Wang, S. Z.; Lu, J. J.; Meng, L. H.; Yao, Z. J. Science China 2010, 53, 119.

14. Al-Oqail, M. M.; Galal, A. M.; Ahmad, M. S.; Al-Fishawi, A. M.; El-Feraly, F. S. Molecules 2003, 8, 901.

15. Galal, A. M.; Ross, S. A.; Jacob, M.; ElSohly, M. A. J. Nat. Prod. 2005, 68, 1274.

16. Haynes, R. K.; Chan, W. C.; Lung, C.-M.; Uhlemann, A.-C.; Eckstein, U.; Taramelli, D.; Parapini, S.; Monti, D.; Krishna, S. Chem. Med. Chem. 2007, 2, 1480. 
17. Avery, M. A.; Bonk, J. D.; Chong, W. K. M.; Mehrotra, S.; Miller, R.; Milhous, W.; Goins, D. K.; Venkatesan, S.; Wyandt, C.; Khan, I.; Avery, B. A. J. Med. Chem. 1995, 38, 5038.

18. Avery, M. A.; Gao, F.; Chong, W. K. M.; Mehrotra, S.; Milhous, W. K. J. Med. Chem. 1993, 36, 4264.

19. Dayan, F. E.; Hernández, A.; Allen, S. N.; Moraes, R. M.; Vroman, J. A.; Avery, M. A.; Duke, S. O. Phytochemistry 1999, 50, 607.

\section{Authors' biographies}

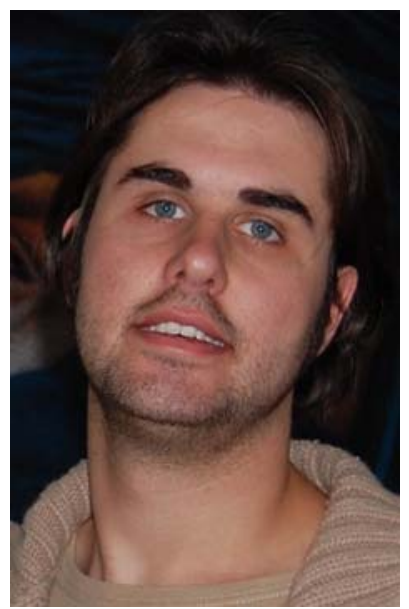

Dr. Jo Alen

Jo Alen received his $\mathrm{PhD}$ in 2007 under the guidance of Professor Georges Hoornaert (K.U.Leuven). After postdoctoral stays in South-Africa (University of Cape Town, 2008) and the United States (The Scripps Research Institute, 2009), he is currently working in the group of Professor Dehaen, on the synthesis of natural products' derivatives.

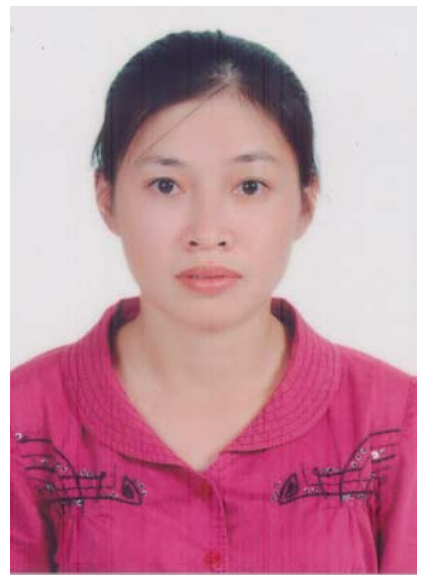

\section{Bich Ngan Truong}

Bich Ngan Truong received a Master of Science at the Institute of Chemistry in 2003. At present she is working in the Laboratory of Organic Synthesis and preparing her PhD degree at the 
Institute of Chemistry - VAST. Her current research interests are natural products and organic synthesis. She has published ten articles in domestic journals.

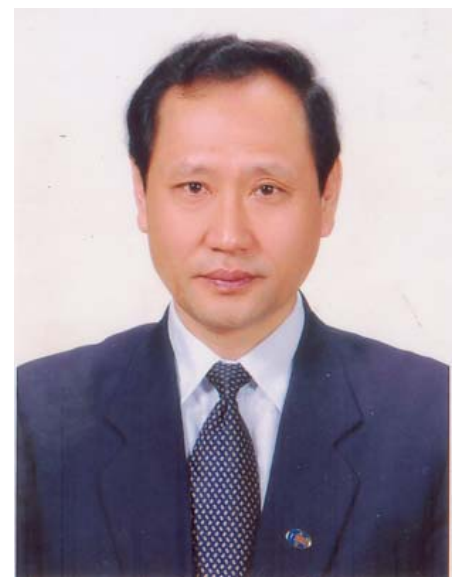

\section{Dr Van Hung Nguyen}

Prof. Nguyen Van Hung obtained BSc, MSc in Organic Chemistry Sofia University in 1975, Ph.D degree in 1989 at the Institute of Chemistry, Academy of Sciences, Moldova (Soviet Union) under the Supervision of Acad. P. Vlad and has been a research professor of VAST since 2007. He has more than 30 years of research experience. His natural products chemistry encompasses bioassay-guided isolation of the anticancer, antimalarial, chemoprevention and anti-HIV/AIDS compounds from Vietnamese plants. In the last 10 years, his research has resulted in more than 200 peer-reviewed articles (in Vietnamese and 70 publications in international journals) describing the isolation of hundred active or novel compounds. Prof. Nguyen Van Hung is Head of Center for Drug Research Development, Principal Investigator of the Franco - Vietnamienne Cooperation "Etude phytochimique de la flore du Vietnam" and Coproject Leader of the project "Biodiversity of Vietnam and Laos".

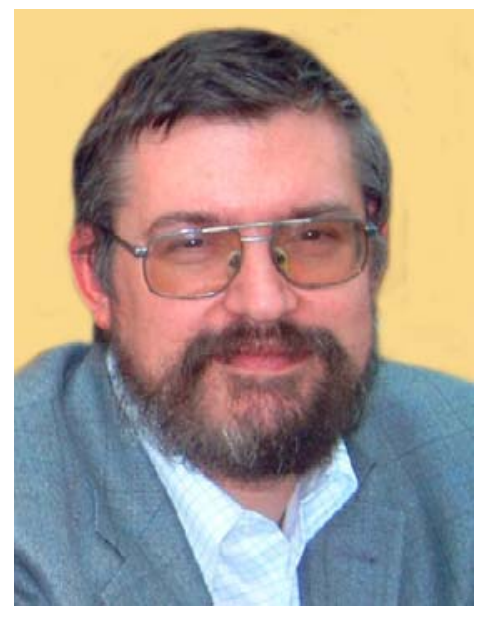

\section{Dr Wim Dehaen}

Wim Dehaen was born in Kortrijk, Belgium. He obtained his PhD in 1988 under the guidance of 
Professor Gerrit L'abbé on a study concerning the rearrangements of 5-diazoalkyl-1,2,3-triazole derivatives. After postdoctoral stays in Israel (1988-1990), Denmark (3 months in 1990), the United Kingdom (three months in 1994) and Belgium (most of 1990-1998) he was appointed associate professor at the University of Leuven (Belgium) in 1998, becoming a full professor at the same university in 2004. Up to 2010, close to 300 publications have appeared in international journals about his work on heterocyclic and supramolecular chemistry. 